\title{
ANALISIS TERJEMAHAN ISTILAH TEKNIK PADA BUKU FUNDAMENTAL OF ENGINEERING THERMODYNAMICS
}

\author{
Fachruddin $^{1}$, Riyadi Santosa ${ }^{2}$, Tri Wiratno ${ }^{3}$ \\ 1,2 Universitas Sebelas Maret \\ ${ }^{2}$ Guru Besar Linguistik Universitas Sebelas Maret, Surakarta, Indonesia \\ ${ }^{1}$ fachruddinmochtar@gmail.com; ${ }^{2}$ riyadisantosa@ staff.uns.ac.id; \\ ${ }^{3}$ wiratno.tri@gmail.com
}

\begin{abstract}
This research focuses on technical terms related to Thermodynamics. This study aims at finding out main domains of technical terms, their forms, their meaning groups, their translation techniques, their translation accuracy, and patterns of their translation. The data were taken from two sources, a source book and its translation version. They were analyzed qualitatively and descriptively. Focus Group Discussion (FGD) was exploited to determine the type of translation technique while questionnaire becomes a method to value the accuracy of translation. Both involved two respondents who have expertise in Translation Studies. Through content analysis, the data were selected purposively. The findings show that the main domains of technical terms are comprised of knowledge concept and knowledge application. Knowledge concept has no further meaning group specifications other than definition while knowledge application consists of five meaning groups. They are equipment, process, position, space, and working fluid. Among those categories, equipment and process hold the highest portion. The translation technique of technical terms is dominated by established equivalence, natural borrowing, and pure borrowing. Meanwhile, the data whose translation techniques were classified into particularization, amplification, and generalization are less than those which were translated through the three translation techniques above. Technical terms expressed as phrases are two times more than those manifested in words. The level of translation accuracy is relatively good $(2.5 \div 2.9$ for knowledge concept and $2.6 \div 2.93$ for knowledge application). Established equivalence mostly contributed to accurate translation. The patterns of technical terms translation are comprised of, first, applied science is the thing which the author of "Fundamental of Engineering Thermodynamics" prioritized. Secondly, phrase is the lingual unit effective to convey the meaning of technical terms from "Fundamental of Engineering Thermodynamics" to its translation version. Thirdly, Indonesian relatively has good effectiveness to cover componential meanings of technical terms in "Fundamental of Engineering Thermodynamics".
\end{abstract}

Keywords: the translation of technical terms, meaning groups, translation techniques, the accuracy of translation 


\begin{abstract}
ABSTRAK
Penelitian ini berfokus pada istilah teknik yang menyangkut bidang Termodinamik. Studi ini bertujuan untuk mengetahui domain induk istilah teknik, bentukbentuknya, macam-macam kelompok maknanya, jenis-jenis teknik penerjemahannya, tingkat keakuratan penerjemahannya, dan pola penerjemahannya. Data diperoleh dari buku sumber dan buku terjemahannya. Data tersebut diinvestigasi secara kualitatif dan deskriptif. Penentuan teknik penerjemahan memakai Focus Group Discussion sedangkan keakuratan hasil terjemahan didasarkan pada kuesioner. Keduanya melibatkan dua responden ahli dalam bidang penerjemahan. Pengumpulan data dilakukan dengan kombinasi antara teknik proporsive sampling dan identifikasi pada dokumen (content analysis). Hasil penelitian menunjukkan bahwa istilah teknik yang terkandung dalam buku tersebut terbagi dalam dua domain induk, konsep keilmuan dan terapan keilmuan. Konsep keilmuan hanya memiliki satu kelompok makna, yaitu definisi, sementara terapan keilmuan dibagi dalam lima kelompok makna, yakni peralatan, proses, kedudukan, ruang, dan fluida kerja. Di antara semua kategori tersebut, peralatan dan proses menduduki peringkat tertinggi. Tiga teknik penerjemahan yang sering dipakai mencakup kesepadanan lazim, natural borrowing, dan pure borrowing. Sementara itu, partikularisasi, amplifikasi, dan generalisasi menempati posisi setelahnya. Istilah teknik yang berbentuk frasa dua kali lebih banyak dari pada yang berbentuk kata. Keseluruhan hasil penerjemahan istilah teknik mempuyai tingkat keakuratan yang relatif baik, domain konsep keilmuan $2,5 \div 2$, 92 dan domain terapan keilmuan $2,6 \div 2$, 93. Kontribusi terhadap keakuratan hasil penerjemahan banyak diberikan oleh teknik kesepadanan lazim. Pola penerjemahan istilah teknik yang tersingkap meliputi, pertama, penerapan sains merupakan hal yang ditonjolkan dalam buku terjemahan Bahasa Indonesia dari Fundamental of Engineering Thermodynamics. Kedua, frasa merupakan bentuk satuan lingual yang efektif untuk menyampaikan makna istilah teknik dari buku Fundamental of Engineering Thermodynamics ke dalam buku versi terjemahan Bahasa Indonesianya. Ketiga, tingkat efektivitas Bahasa Indonesia sebagai bahasa sasaran untuk menyampaikan makna istilah teknik dari buku Fundamental of Engineering Thermodynamics relatif baik.
\end{abstract}

Kata kunci: penerjemahan istilah teknik, kelompok makna, teknik penerjemahan, keakuratan terjemahan.

\title{
PENDAHULUAN
}

Termodinamika adalah salah satu cabang dari bidang ilmu Fisika yang membahas perubahan dari energi panas dan energi fluida menjadi energi mekanik. Ilmu ini menjadi kompetensi mahasiswa program studi Teknik Konversi, Teknik Mesin, Fisika Teknik, dan Prodi-prodi Teknik Industri lainnya. Ilmu Termodinamika serumpun dengan ilmu Mekanika Fluida dan Ilmu Perpindahan panas. Adapun penerapan rumpun ilmu ini meliputi mesin-mesin pompa, kompresor, turbin, boiler, alat penukar panas, dan lain-lain. 
Dalam beberapa buku tentang termodinamika, istilah teknik dalam Bahasa Inggris $(\mathrm{BSu})$ diterjemahkan dalam Bahasa Indonesia (BSa) dengan aneka macam padanan. Misalnya, superheated steam yang berpengertian 'keadaan uap basah yang dipanaskan lagi hinggga uap tersebut tidak mengandung air' diterjemahkan menjadi uap panas lanjut, uap kering, dan uap superpanas. Steady flow yang berdefinisikan 'keadaan aliran fluida yang seragam' diterjemahkan menjadi aliran tunak atau aliran stasioner. Absolute temperature yang berarti 'suhu mutlak' diterjemahkan menjadi temperatur absolut atau temperatur mutlak. Hal ini menunjukkan bahwa penerjemahan istilah teknik-istilah teknik dalam buku-buku teknik diterjemahkan menjadi berbagai istilah oleh penerjemahnya. Oleh karena itu, diperlukan panduan dan standar yang dapat menjaga konsistensi dalam proses penerjemahan guna menghasilkan terjemahan yang berkualitas.

Dalam buku Termodinamika Teknik susunan Yulianto Sulistyo Nugroho yang merupakan terjemahan dari buku Fundamental of Engineering Thermodynamics karangan Michael J. Moran, terdapat beberapa terjemahan istilah teknik, seperti adiabatic-adiabatik, compressible flow - aliran mampu mampat dan lain sebagainya. Dari temuan diatas, dapat dinyatakan bahwa ada beberapa teknik penerjemahan yang dipakai. Dalam penelitian ini, kecenderungan teknik penerjemahan yang umumnya dipakai dalam buku-buku teknik versi terjemahan akan dikupas secara detil.

Selain itu, ditemukan bahwa istilah teknik-istilah teknik tersebut ternyata mempunyai makna yang berbeda-beda, namun bisa digolongkan dalam domain induk konsep keilmuan dan terapan keilmuan. Mereka kemudian diperinci lagi ke dalam kelompok makna-kelompok makna tertentu, di antaranya definisi, peralatan, ruang, besaran, kedudukan, dan fluida kerja. Penelitian ini juga akan membahas teknik penerjemahan istilah teknik, keakuratan penerjemahannya, serta pola penerjemahannya.

Sementara itu, tujuan penerjemahan adalah menyajikan pesan dan informasi dari bahasa sumber $(\mathrm{BSu})$ ke bahasa sasaran (BSa) dengan sebaik mungkin (dari materi aslinya) sehingga pembaca mampu memahami pesan dan informasi dari penulis buku. Penerjemahan istilah teknik ini selain memerlukan pemahaman pesan yang disampaikan, juga menuntut kualitas terjemahannya. Salah satu aspek dari kualitas penerjemahan adalah keakuratan penerjemahan. Suatu terjemahan yang tidak berkualitas akan mudah menimbulkan multi interpretasi bagi pembaca. Sebaliknya, 
produk terjemahan yang berkualitas akan sangat membantu hal yang paling hakiki, yaitu transfer informasi dari pengarang kepada pembaca.

Untuk mengetahui teknik penerjemahan yang dipakai dalam buku Fundamental of Engineering Thermodynamics karangan Michael J. Moran yang diterjemahkan oleh Yulianto Sulistyo Nugroho (2004), pertama-tama peneliti akan menjaring seluruh satuan lingual yang dikategorikan dalam data. Data yang dimaksud adalah setiap kata, frasa, klausa, atau kalimat yang memuat dan mendukung pengertian istilah teknik. Kemudian, data yang bersangkutan dianalisa berdasarkan teknik penerjemahan yang dipakai.

Sumber data pertama adalah buku sumber dan produk terjemahannya. Kedua sumber data ini berperan sebagai sumber data objektif. Sumber data kedua diperoleh dari informan yang memberi informasi mengenai keakuratan hasil terjemahan. Dengan kata lain, sumber data ini merupakan sumber data afektif. Pengumpulan data dilakukan melalui pengkajian dokumen, penyebaran kuesioner, dan wawancara mendalam. Pemilihan sampel data dilakukan dengan teknik purposive sampling. Hasil analisis teknik penerjemahan dan analisis penilaian kualitas penerjemahan kemudian disandingkan guna menemukan rekomendasi teknik penerjemahan yang tepat untuk istilah teknik yang bersangkutan.

(Sakut, 2010), dalam eksplorasinya terhadap buku Economic Concepts of Ibn Taimiyah yang diterjemahkan dalam Bahasa Indonesia, menyatakan bahwa penerjemahan buku tersebut cenderung menggunakan metode terjemahan harfiah dengan ideologi forenisasi. Dampak dan penggunaan teknik penerjemahan terhadap kualitas terjemahan cukup baik, dengan rata-rata skor keakuratan terjemahan 2, 53, keberterimaan 2, 73, dan keterbacaan 2, 91.

Dalam Analisis Teknik dan Kualitas Terjemahan Istilah Budaya dalam "Film Percy Jackson and The Olympians Thief” (Nurhidayah, 2015), menemukan dua sifat teknik yaitu obligatory dan optional. Teknik harfiah dengan frekuensi kemunculan 44 kali merupakan teknik yang paling banyak digunakan, diikuti dengan teknik peminjaman murni yang penggunaannya $20 \mathrm{kali}$, dan peminjaman naturalisasi dengan total pemakaian 9 kali. Secara keseluruhan, kualitas terjemahan istilah budaya dalam subtitle film Percy Jackson and The Olympians The Lightning Thief tergolong baik, dengan rincian nilai 2, 84 untuk keakuratan dan 2, 76 untuk keberterimaan. 
Demikian juga Yahya (2014) dalam Analisis Terjemahan Kata-kata Kultural dalam Novel "Pride and Prejudice" dan Novel Terjemahannya "Keangkuhan dan Prasangka" menyatakan bahwa dengan teknik analisis data dari Spradley dan metode kuesioner, teridentifikasi 213 kata-kata kultural yang dapat digolongkan dalam kategori 1) ekologi: 12 (6,10\%), 2) budaya materi: 45 (21,13\%), 3) budaya sosial: 7 (3,29\%), 4) organisasi, tradisi, aktivitas, prosedur dan konsep: 134 (62,91\%), dan 5) gesture: 15 $(7,04 \%)$. Kualitas terjemahan tercermin dari rata-rata tingkat keakuratan, keberterimaan, dan keterbacaan yang secara urut skornya 2, 53, 2, 64, dan 2, 83. Dengan angka rerata 2, 62, hal ini menunjukkan bahwa secara keseluruhan, kualitas terjemahan dalam penelitian ini termasuk dalam kategori baik. Untuk meminimalisir terjadinya translation loss, meaning loss, dan cultural loss, penjabaran forenisasi dan domestikasi (penerapan teknik penerjemahannya) perlu diramu dengan fleksibel.

Dalam penelitian berjudul Analisis Terjemahan Istilah Komputer dan Teknologi Informasi dalam Film "The Social Network" serta Dampaknya pada Kualitas Terjemahan (Kajian Terjemahan dengan Pendekatan Sosio pragmatik), (Sigalingging, 2014) menyatakan bahwa dalam hasil penelitiannya, ditemukan (1) 6 ranah sosial, yaitu pertemanan, media, hukum, pendidikan, pekerjaan, dan kemasyarakatan beserta 18 macam makna sosio pragmatik, yaitu sosiopragmatik pemberitahuan, penjelasan, ajakan, sindiran, permintaan, anjuran, peringatan, pancingan, pemberian kesaksian, pengungkapan fakta hukum, dakwaan, pemberian jawaban, tawaran, penolakan, desakan, suruhan, instruksi, dan larangan, dan (2) 11 teknik penerjemahan, yaitu pemadanan lazim, peminjaman murni, peminjaman yang sudah dinaturalisasi, penerjemahan harfiah, modulasi, generalisasi, transposisi, partikularisasi, kalke, reduksi, dan amplifikasi linguistik. Putra, D.A. \& Wiratno, (2017) dalam penelitiannya istilah teknik dikelompokkan dalam kelompok informasi umum, deskripsi barang, dan deskripsi skill.

Dalam hal kualitas, mayoritas penerapan teknik peminjaman, pemadanan lazim, penerjemahan harfiah, transposisi, generalisasi, partikularisasi, dan amplifikasi linguistik menghasilkan terjemahan istilah komputer dan teknologi informasi yang akurat, berterima, dan memiliki keterbacaan tinggi. Sementara itu, mayoritas penerapan teknik modulasi, kalke, dan reduksi menghasilkan terjemahan istilah komputer dan 
teknologi informasi yang kurang atau tidak akurat, kurang atau tidak berterima, dan dengan keterbacaan sedang.

Aisiyah (2014), dalam penelitianyang berjudul Penerjemahan Istilah Mekanika Teknik dari Bahasa Inggris ke Bahasa Indonesia: Studi Kasus Buku Teks "Statically Indeterminate Structures" karya Chu-kia Wang dan Buku Teks "Struktur Statistik Tentu” karya Herman Widodo Soemitro, telah menginvestigasi sebanyak 104 istilah yang berupa kata tunggal dan frasa. Semua istilah itu dianalisa tanpa mengaitkan konteksnya dalam kalimat. Penelitian tersebut menggunakan model penelitian komparatif dengan membandingkan antara buku teks yang berbahasa Inggris dan buku teks terjemahan Bahasa Indonesia. Dari hasil analisis keakuratan terjemahan, diperoleh istilah Bahasa Indonesia yang dinilai akurat, kurang akurat, dan tidak akurat. Selain itu, diperoleh pembentukan istilah padanan dalam Bahasa Indonesia.

Dari pemaparan diatas, ada celah yang akan digunakan di dalam penelitian ini, yakni domain induk istilah teknik serta bentuknya, sebaran istilah teknik dalam kelompok maknanya, penggunaan teknik penerjemahannya, keakuratan hasil penerjemahannya, dan pola penerjemahannya.

\section{TEORI DAN METODOLOGI}

\section{Teori}

Menurut (Larson, 1984) bahwa penerjemahan merupakan pengubahan bentuk ke dalam bentuk lain atau pengubahan dari suatu bahasa ke dalam bahasa lain; dalam penerjemahan, bahasa sumber diganti dengan bentuk bahasa sasaran; penerjemahan merupakan proses yang rumit, tetapi penerjemah yang mahir akan menemukan cara untuk mengungkapkan makna yang dimaksud walaupun bentuk baru itu mungkin sangat berbeda dengan bentuk bahasa sumber. Munday (2005) berpendapat bahwa penerjemahan berkaitan dengan produk teks yang telah diterjemahkan; penerjemahan berkaitan pula dengan proses menghasilkan terjemahan dari dua bahasa yang berbeda, yakni bahasa sumber dan bahasa sasaran.

Penerjemahan, menurut (Catford, 1978), merupakan proses penggantian suatu teks bahasa sumber dengan teks bahasa sasaran; penerjemahan merupakan penggantian materi teks bahasa sumber ke materi teks bahasa sasaran (the replacement of textual material in one language (source language) by equivalent textual material in another 
language (target language)).) Penerjemahan adalah pengartian sedekat mungkin dalam bahasa sasaran seperti bahasa sumbernya, baik menyangkut makna maupun bentuk (Chesterman, 2017). (Nababan, 2012) mengemukakan bahwa penerjemah yang kompeten seharusnya seorang bilingual, yakni (i) orang yang mampu menggunakan bahasa dan (ii) orang yang dapat menggunakan dua bahasa karena belajar dua bahasa sejak kecil. Unsur penting sebagai landasan untuk sebuah penerjemahan adalah pengetahuan penerjemah yang mendalam mengenai kaidah atau tata bahasa bahasa sumber dan bahasa sasaran; dengan demikian, penerjemah dapat mengedapankan pemindahan makna dalam penerjemahan.

Karya terjemahan merupakan penilaian aktif dari si penerjemah dalam upaya untuk memberikan padanan yang praktis dari teks asli dan yang cocok dengan selera lingkungan penerjemah (Molina, 2002); terjemahan yang praktis dari suatu teks asli harus memenuhi tiga dimensi, yaitu dimensi pengetahuan, dimensi tujuan, dan dimensi intuisi; dimensi pengetahuan mengharuskan suatu karya terjemahan memperlihatkan kecocokan makna antara kebudayaan pengarang asli dan kebudayaan masyarakat pembaca karya terjemahan; dimensi tujuan menekankan agar karya terjemahan berhasil mencapai tujuan yang didefinisikan oleh penerjemah; dimensi intuisi mengupayakan agar terjemahan mampu memuaskan penggunanya.

\section{Metodologi}

Penelitian ini bertujuan untuk mengidentifikasi dan mendeskripsikan kualitas terjemahan dari sebuah buku. Oleh karena itu, jenis penelitian ini adalah deskriptifkualitatif. Penelitian ini dikategorikan sebagai penelitian terpancang karena, seperti yang tercantum dalam rumusan masalah dan batasan masalah, peneliti telah menentukan pokok permasalahan dan fokus investigasi terlebih dahulu. Kemudian, karena peneliti hanya ingin memahami suatu masalah secara individual untuk kepentingan akademik dan untuk mendeskripsikan secara rinci mengenai pokok permasalahan (Sutopo, 2006), penelitian ini diklasifikasikan sebagai penelitian dasar.

Selain itu, ditegaskan oleh (Maleong, 2000) bahwa penelitian deskriptif berkutat pada data yang berupa kalimat dan sejenisnya, bukan data numerik atau statistik, dalam mendeskripsikan analisis. Selanjutnya, penelitian ini termasuk dalam studi kasus tunggal karena sasaran atau subjeknya memiliki karakteristik yang sama, dan termasuk 
dalam penelitian pada bidang penerjemahan yang berorientasi pada produk. Sumber data dalam penelitian kualitatif dapat berupa nara sumber (informan), peristiwa atau aktivitas, tempat atau lokasi, benda, beragam gambar, dan rekaman (Sutopo, 2000). Sementara itu, data adalah objek penelitian atau realitas yang dijadikan fokus penelitian.

\section{TEMUAN DAN PEMBAHASAN}

Istilah adalah kata atau gabungan kata yang dengan cermat mengungkapkan makna konsep, proses, keadaan, atau sifat yang khas dalam bidang tertentu. Istilah istilah teknik seperti : sistem tertutup, volume atur, massa atur, sistem terbuka, Skala Kelvin, Hukum gerak Newton, mekanika klasik, sistim sederhan, kerja, energi kinetik, energi potensial, massa benda, kecepatan, Kerja netto, keluaran kerja dimasukkan dalam kelompok makna Definisi karena istilah tersebut merumuskan tentang ruang lingkup dan ciri-ciri suatu konsep yang menjadi pokok kajian dan mengandung pengertian dan batasan-batasan tertentu. Istilah-istilah kondisi tunak, kesetimbangan termal, dua phase keadaan cair-uap, temperatur jenuh, perubahan fase, tekanan jenuh, reversible, reversible internal, adiabatic, entropi, pemanasan ulang dimasukkan dalam kelompok Proses karena istilah tersebut menunjukkan berlangsungnya suatu proses.

Istilah-istilah termokopel, diffuser, pembangkit uap, boiler, pemanas air, penukar kalor, mesin pembakaran dalam, busi, dimasukkan dalam kelompok Peralatan karena istilah tersebut bermakna peralatan yang membantu terjadinya suatu proses. Istilah-istilah refrijeran, absorben, larutan cair.dimasukkan kedalam kelompok Fluida kerja karena istilah-istilah tersebut bermakna fluida (zat alir) yang berproses didalam suatu peralatan. Istilah-istilah batas system, ruang, permukaan atur, volume sisa, volume perpindahan, combustion chamber dimasukkan dalam kelompok Ruang karena istilah tersebut menunjukkan ruang tempay berlangsungnya suatu proses yang nyata maupun imajiner.

Sesuai teknik purposive sampling, maka data-data yang diperoleh dapat disajikan seperti gambar 1. 


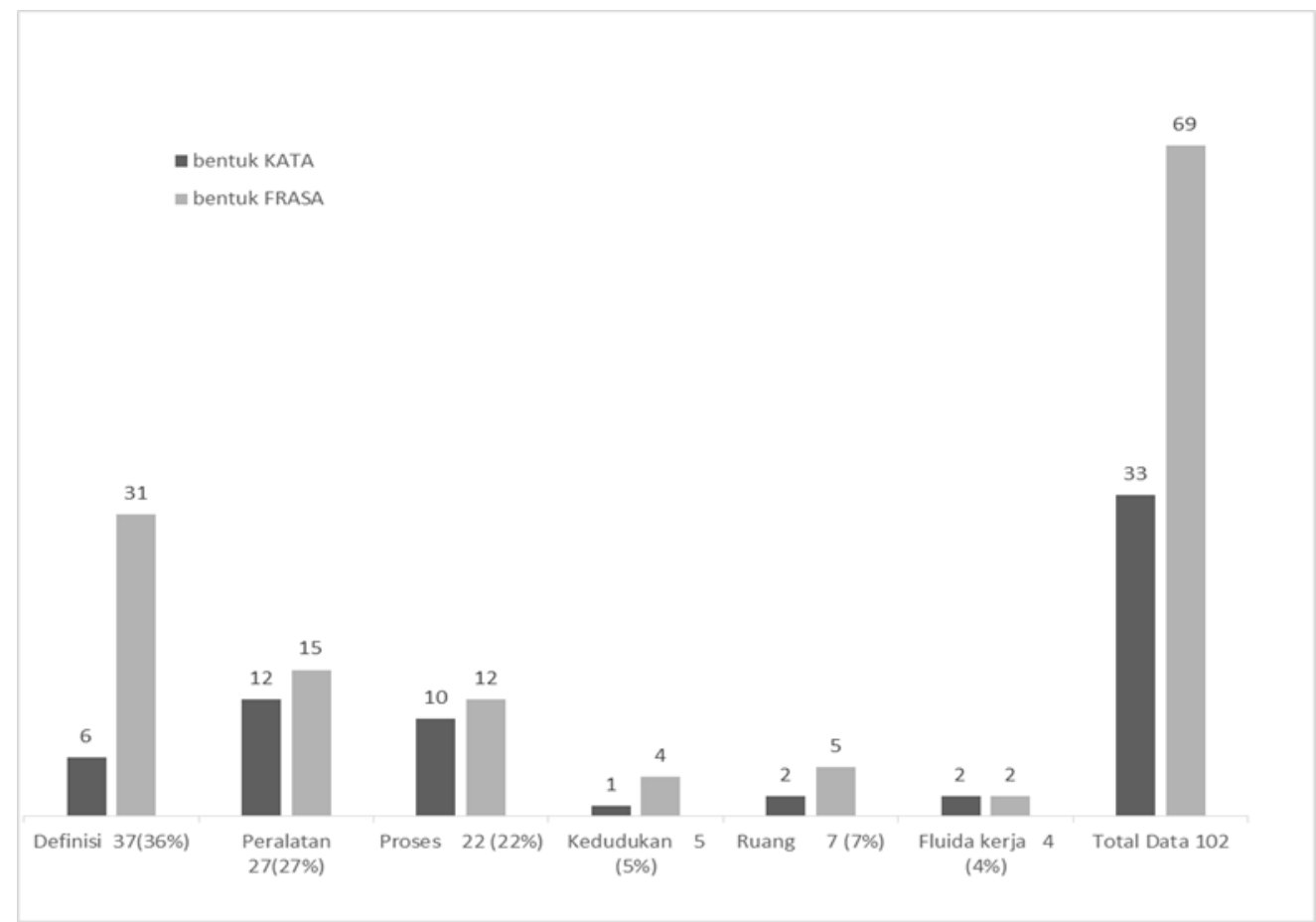

Gambar 1. Bentuk istilah teknik serta distribusinya dalam kelompok maknanya

Dari gambar 1, terlihat bahwa semua data dipilah dan dikelompokkan dalam kelompok makna Definisi, Peralatan, Proses, Kedudukan, Ruang, dan Fluida kerja. Dan masing-masing kelompok diperinci menjadi bentuk kata dan frasa. Istilah berbentuk frasa 69 (68\%) dan berbentuk kata 33 (32\%), dengan lebih banyaknya bentuk frasa ini menguatkan pernyataan bahwa frasa lebih mampu memberikan makna yang lebih luas dalam menyampaikan pesan.

Demikian juga jumlah istilah kelompok Definisi sebanyak 37 (36\%) sedangkan selainnya bisa disebut dengan kelompok Terapan 65 (64\%), ini juga menguatkan bahwa buku yang diterjemahkan adalah buku tentang teknik yang memuat istilah makna Terapan lebih banyak daripada istilah Definisi yang hanya membahas sains saja.

\section{Penggunaan teknik penerjemahan}

Dalam proses penerjemahan ini ada beberapa teknik yang dipakai yakni Kesepadanan Lazim, Natural Borrowing, Pure Borrowing, Partikulasi, Amplifikasi dan Generalisasi. Pada data yang berbentuk frasa, umumnya diterjemahkan dengan lebih dari satu teknik, beberapa contoh disampaikan untuk menunjukkan pemakaian masingmasing. 


\section{Contoh penerjemahan dengan teknik Kesepadanan lazim}

Bsu : Some gas turbine power plants take advantage of the excess air by means of a multistage turbine with a reheat combustor between the stages.

Bsa : Beberapa pembangkit tenaga turbin gas memanfaatkan udara berlebih ini melalui penerapan turbin multi-tingkat yang dilengkapi dengan reheat combustor.

Udara berlebih adalah istilah untuk menyatakan suatu proses pembakaran dengan penyediaan udara melebihi kebutuhannya, hal ini dimaksudkan agar ada jaminan proses pembakaran terjadi dengan sebaik-baiknya.

Excess air diterjemahkan menjadi udara berlebih dengan teknik Kesepadanan lazim, padanan demikian memang dengan mudah dicari dalam kamus bahasa, hal demikian sekaligus bisa menyatakan bahwa bahasa Indonesia sudah baik dan memadai dalam mengalihkan bahasa istilah dari Bsu menjadi Bsa.

\section{Contoh penerjemahan dengan teknik Natural borrowing}

Bsu : The net heat transfer from the refrigerant equals the network done on the refrigerant.

Bsa :Perpindahan kalor netto dari refrijeran sebanding dengan kerja netto yang dilakukan pada refrijeran.

Refrigerant adalah istilah yang menunjukkan fluida kerja yang dipakai dalam sistim pendinginan mesin Refrigeration, istilah tersebut diterjemahkan menjadi refrijeran. Agak sulit untuk mencari padanannya dalam bahasa Indonesia, karena istilah tersebut spesifik pemakaiannya untuk menunjukkan fluida kerja pada sistim pendingin, dan istilah tersebut tidak bisa pada sistim lainnya, misalnya pada sistim kompressi atau lainnya. Maka pilihannya adalah meminjam istilah dalam bahasa aslinya dan mengadakan naturalisasi atasnya hingga menjadi refrijeran.

\section{Contoh penerjemahan dengan teknik Pure borrowing}

Bsu : Some gas turbine power plants take advantage of the excess air by means of a multistage turbine with a reheat combustor between the stages.

Bsa : Beberapa pembangkit tenaga turbin gas memanfaatkan udara berlebih ini melalui penerapan turbin multi-tingkat yang dilengkapi dengan reheat combustor.

Reheat combustor adalah combustor lanjutan yang berfungsi untuk melakukan pemanasan ulang terhadap gas yang keluar dari turbin pertama untuk dialirkan ke turbin kedua atau selanjutnya. Istilah ini selain tidak ada padanannya dalam bahasa Indonesia juga sangat spesifik penggunaannya, hingga kita pinjam istilah diatas sebagaimana aslinya. 


\section{Contoh penerjemahan dengan teknik Kesepadanan lazim-Natural borrowing}

Bsu : To introduce some important aspects of vapor refrigeration, let us begin by considering a Carnot vapor refrigeration cycle.

Bsa : Untuk nenperkenalkan aspek-aspek dari refrijerasi uap, mari kita mulai memperhatikan siklus refrijerasi uap carnot.

Pada contoh ini, refrigeration cycle diterjemahkan dengan dua teknik yakni Kesepadanan lazim pada kata cycle menjadi siklus dan dengan teknik natural borrowing pada kata refrigeration menjadi refrijerasi. Kita tidak mendapatkan padanan kata refrigeration dalam bahasa kita karena memang istilah tersebut merupakan produk pengembangan teknologi dalam ilmu termodinamika.

\section{Contoh penerjemahan dengan teknik Kesepadanan lazim-Particulation}

Bsu : With reheat, a power plant can take advantage of the increased efficiency that results

Bsa : Dengan pemanasan ulang, suatu instalasi pembangkit uap dapat memanfaatkan peningkatan effisiensi yang dihasilkan.

Istilah power plant diterjemahkan menjadi pembangkit uap, sebetulnya secara umum power plant bisa diterjemahkan menjadi pembangkit enerji, kata pembangkit namun penulis memilih teknik partikulasi hingga hasil terjemahan menjadi lebih detil dan konkrit dalam menyampaikan pesan dalam konteks buku ini.

\section{Contoh penerjemahan dengan teknik Kesepadanan lazim-Amplifikasi}

Bsu : The system is distinguished from its surroundings by a specified boundary

Bsa : Sistem dipisahkan dengan lingkungannya oleh batas sistem.

Pada contoh diatas istilah specified boundary diterjemahkan menjadi batas sistim, istilah ini berbentuk frasa yang terdiri dari dua kata, kata boundary mendapat kesepadanannya dengan kata batas sedangkan specified diterjemahkan oleh penulis sebagai sistim, yang sebetulnya kata padanan specified adalah tetap. Pilihan kata sistim untuk menerjemahkan kata specified karena hasil terjemahan ini lebih eksplisit dari pada jika diterjemahkan menjadi batas khusus atau batas tertentu, maka dipilih teknik Amplifikasi karena dengan teknik ini hasil penerjemahan menjadi lebih jelas dan pesan yang disampaikan lebih effektif. 


\section{Contoh penerjemahan dengan teknik Kesepadanan lazim-Generalisasi}

Bsu : The air then enters a combustion chamber.

Bsa : Udara yang telah dikompresi tersebut kemudian masuk ke dalam ruang bakar.

Pada contoh ini combustion chamber oleh penulis diterjemahkan secara Generalisasi menjadi ruang bakar, memang dengan penerjemahan demikian maknanya bisa menjadi lebih umum dan bisa berlaku untuk motor pembakaran dalam (internal combustion engine) maupun turbin gas.

Tabel 1. Sebaran Teknik Penerjemahan

\begin{tabular}{|c|c|c|c|c|c|c|c|c|c|c|}
\hline & & & $\begin{array}{c}\text { Kesepadan } \\
\text { an Lazim }\end{array}$ & $\begin{array}{c}\text { Nat } \\
\text { Borrowing }\end{array}$ & $\begin{array}{c}\text { Pure } \\
\text { Borrowing }\end{array}$ & $\begin{array}{l}\text { K Lazim + } \\
\text { Nat Borrow }\end{array}$ & $\begin{array}{c}\text { K Lazim + } \\
\text { Pure Borrow }\end{array}$ & $\begin{array}{l}\text { K Lazim + } \\
\text { Partikulasi }\end{array}$ & $\begin{array}{c}\text { K Lazim + } \\
\text { Amplifikasi }\end{array}$ & $\begin{array}{c}\text { K Lazim + } \\
\text { Generalisasi }\end{array}$ \\
\hline Definisi & 37 & $(36 \%)$ & 11 & 3 & 1 & 21 & 1 & 0 & 0 & 0 \\
\hline Peralatan & 27 & $(27 \%)$ & 5 & 6 & 9 & 6 & 0 & 1 & 0 & 0 \\
\hline Proses & 22 & $(22 \%)$ & 10 & 4 & 2 & 5 & 1 & 0 & 0 & 0 \\
\hline Kedudukan & 5 & $(5 \%)$ & 4 & 0 & 0 & 0 & 0 & 1 & 0 & 0 \\
\hline Ruang & 7 & $(7 \%)$ & 3 & 0 & 0 & 1 & 0 & 1 & 1 & 1 \\
\hline \multirow[t]{3}{*}{ Fluida kerja } & 4 & $(4 \%)$ & 1 & 2 & 0 & 0 & 1 & 0 & 0 & 0 \\
\hline & & & 34 & 15 & 12 & 33 & 3 & 3 & 1 & 1 \\
\hline & & & $33 \%$ & $15 \%$ & $12 \%$ & $32 \%$ & $3 \%$ & $3 \%$ & $1 \%$ & $1 \%$ \\
\hline
\end{tabular}

Dari Tabel 1 diatas nyatalah bahwa Kesepadanan Lazim mendominasi teknik penerjemahan baik secara mandiri 34 (37\%), maupun jika bersama dengan teknik lain $41(40 \%)$ hal terakhir terutama pada penerjemahan istilah yang berbentuk frasa yang memerlukan tidak cukup dengan satu teknik penerjemahan, demikian juga jika diperhatikan pada penerjemahan pada masing-masing kelompok makna bahwa Kesepadanan lazim lebih sering dipakai sebagai teknik penerjemahan. Berikutnya adalah pemakaian teknik Natural Borrowing dan Pure Borrowing masing-masing 15 $(15 \%)$ dan 12 (12\%). Sedangkan pemakaian teknik Partikulasi, Amplifikasi dan Generalisasi relative kecil dan dipakai bersama dengan teknik Kesepadanan lazim. Istilah makna Definisi banyak berupa frasa hingga penerjemahannya didominasi dengan teknik Kesepadanan lazim bersama dengan teknik Natural borrowing. Ini pula terlihat pada penerjemahan istilah Peralatan maupun Proses.

Dengan ini dapat dinyatakan bahwa Kesepadanan lazim dan Borrowing adalah teknik penerjemahan yang paling banyak dipakai, seperti pada hasil penelitian bidang sosial oleh Nurhidayah (2014), dan pada hasil penelitian istilah kedokteran oleh 
Widarwati (2015). Secara umum bisa dikatakan bahwa dua teknik penerjemahan diatas secara empiris dianjurkan dipakai dalam semua bidang keilmuan, maka ada baiknya bahwa teknik-teknik penerjemahannya ini perlu pengembangan metodenya. Dominasi teknik Kesepadanan Lazim dalam penerjemahan ini patut disambut gembira karena ini merupakan indikator bahwa bahasa Indonesia bisa menunjukkan kemampuannya menjadi alat penyampai pesan yang baik dari bahasa Inggris pada rumpun ilmu teknik.

\section{c. Keakuratan hasil penerjemahan}

Model penilaian kualitas terjemahan disampaikan oleh Nababan (2012). Menurutnya, kualitas terjemahan dapat dilihat dari beberapa aspek: (i) keakuratan (accurate), yakni pesan teks bahasa sumber harus dialihkan secara utuh/akurat, (ii) keberterimaan (acceptable), yakni terjemahan harus sesuai dengan kaidah dan budaya yang berlaku dalam bahasa sasaran, dan (iii) keterbacaan (readable), yakni terjemahan harus dapat dipahami dengan mudah oleh pembaca sasaran.

Dalam pelaksanaan penilaian kualitas terjemahan perlu ditentukan penilai (rater) dengan kualifikasi tertentu yang mampu memberikan penilaian secara tepat. Kualifikasi penilai keakuratan, keberterimaan, dan keterbacaan menurut Nababan (2012) sebagai berikut. Kriteria penilaian keakuratan adalah (i) penerjemah profesional dan berpengalaman di bidang penerjemahan teks-teks ilmiah dari bahasa Inggris ke dalam bahasa Indonesia, (ii) memiliki kompetensi penerjemahan yang baik, yang terdiri atas kompetensi kebahasaan, kompetensi wacana, kompetensi budaya, kompetensi bidang ilmu, kompetensi strategik, dan kompetensi transfer, dan (iii) memiliki pengetahuan deklaratif dan pengetahui prosedural atau operatif yang baik. Kriteria penilaian keberterimaan adalah (i) menguasai penggunaan tatabahasa baku bahasa Indonesia, (ii) menguasai bidang ilmu dari teks terjemahan, dan (iii) akrab dengan istilah teknis dalam bidang teks terjemahan yang dinilai. Kriteria keterbacaan adalah (i) mampu membaca dan memahami teks berbahasa Indonesia dengan baik, dan (ii) merupakan pembaca ideal dari suatu teks terjemahan yang dinilai.

Masing masing instrumen terdiri dari tiga bagian yaitu kategori terjemahan, skor, dan parameter. Ada tiga kategori yakni akurat, kurang akurat, tidak akurat yang masing-masing diberi skor 3, 2, dan 1 . 
Penelitian ini lebih menyoroti pada aspek keakuratan, dari data yang dipilih dapat diolah menjadi seperti pada tabel berikut.

Tabel 2 Data dan skor keakuratan

\begin{tabular}{|c|c|c|c|c|c|c|c|c|c|c|c|c|c|c|c|c|c|c|c|c|c|c|c|c|}
\hline & \multicolumn{24}{|c|}{ Teknik Penerjemahan } \\
\hline & \multicolumn{3}{|c|}{$\begin{array}{l}\text { Kesepadanan } \\
\text { Lazim }\end{array}$} & \multicolumn{3}{|c|}{ Natural Borrowing } & \multicolumn{3}{|c|}{ Pure Borrowing } & \multicolumn{3}{|c|}{$\begin{array}{c}\text { Kes Lazim + } \\
\text { Natural Borrowing }\end{array}$} & \multicolumn{3}{|c|}{$\begin{array}{l}\text { Kes Lazim + Pure } \\
\text { Borrowing }\end{array}$} & \multicolumn{3}{|c|}{$\begin{array}{l}\text { Kes Lazim + } \\
\text { Partikularisasi }\end{array}$} & \multicolumn{3}{|c|}{$\begin{array}{l}\text { Kes Lazim + } \\
\text { Amplifikasi }\end{array}$} & \multicolumn{3}{|c|}{$\begin{array}{l}\text { Kes Lazim + } \\
\text { Generalisasi }\end{array}$} \\
\hline Kelompok makna & 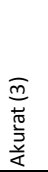 & 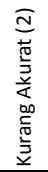 & 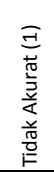 & $\begin{array}{l}\widehat{m} \\
\frac{\pi}{\pi} \\
\frac{\pi}{3} \\
\frac{v}{4}\end{array}$ & 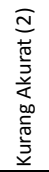 & 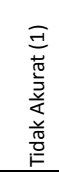 & 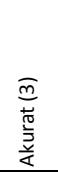 & 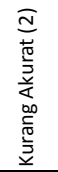 & 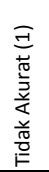 & 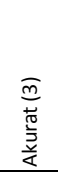 & 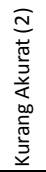 & 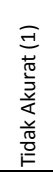 & 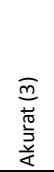 & 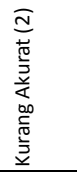 & 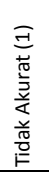 & 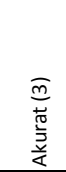 & 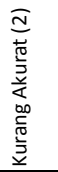 & 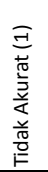 & 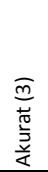 & 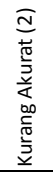 & 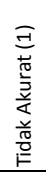 & $\begin{array}{l}\bar{m} \\
\stackrel{0}{0} \\
\frac{0}{3} \\
\frac{\vec{v}}{\alpha}\end{array}$ & 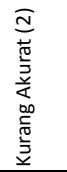 & 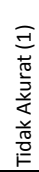 \\
\hline Definisi $37(36 \%)$ & 10 & 1 & 0 & 2 & 1 & 0 & 0 & 1 & 0 & 19 & 2 & 0 & 1 & 0 & 0 & 0 & 0 & 0 & 0 & 0 & 0 & 0 & 0 & 0 \\
\hline skor & & & 2.91 & & & 2.67 & & & 2.00 & & & 2.90 & & & 3.00 & & & & & & & & & \\
\hline $\begin{array}{l}\text { Peralatan } 27(27 \%) \\
\end{array}$ & 5 & 0 & 0 & 4 & 2 & 0 & 6 & 3 & 0 & 6 & 0 & 0 & 0 & 0 & 0 & 1 & 0 & 0 & 0 & 0 & 0 & 0 & 0 & \\
\hline skor & & & 3 & & & 2.667 & & & 2.67 & & & 3 & & & 0 & & & 3 & & & 0 & & & \\
\hline Proses $22(22 \%)$ & 7 & 3 & 0 & 3 & 1 & 0 & 1 & 1 & 0 & 4 & 1 & 0 & 1 & 0 & 0 & 0 & 0 & 0 & 0 & 0 & 0 & 0 & 0 & \\
\hline skor & & & 2.7 & & & 2.75 & & & 2.5 & & & 2.8 & & & 3 & & & & & & & & & \\
\hline Kedudukan 5(5\%) & 2 & 2 & 0 & 0 & 0 & 0 & 0 & 0 & 0 & 0 & 0 & 0 & 0 & 0 & 0 & 1 & 0 & 0 & 0 & 0 & 0 & 0 & 0 & \\
\hline skor & & & 2.5 & & & 0 & & & 0 & & & 0 & & & 0 & & & 3 & & & 0 & & & \\
\hline Ruang $7(7 \%)$ & 2 & 1 & 0 & 0 & 0 & 0 & 0 & 0 & 0 & 1 & 0 & 0 & 0 & 0 & 0 & 0 & 1 & 0 & 0 & 1 & 0 & 1 & 0 & \\
\hline skor & & & 2.67 & & & 0 & & & 0 & & & 3 & & & 0 & & & 2 & & & 2 & & & \\
\hline Fluida Kerja 4 (4\%) & 1 & 0 & 0 & 2 & 0 & 0 & 0 & 0 & 0 & 0 & 0 & 0 & 1 & 0 & 0 & 0 & 0 & 0 & 0 & 0 & 0 & 0 & 0 & \\
\hline skor & & & 3 & & & 3 & & & 0 & & & 0 & & & 3 & & & 0 & & & 0 & & & \\
\hline
\end{tabular}

$\begin{array}{cccccccc}\text { Skor rata2 } & \text { Skor rata2 } & \text { Skor rata2 } & \text { Skor rata2 } & \text { Skor rata2 } & \text { Skor rata2 } & \text { Skor rata2 } & \text { Skor rata2 } \\ 2.79 & 2.73 & 2.58 & 2.91 & 3.00 & 2.67 & 2.00 & 3.00\end{array}$

Dalam tabel 2 diatas menunjukkan bahwa hasil terjemahan mempunyai keakuratan yang baik, yakni mempunyai skor keakuratan $2,91 \div 2,50$. Hasil terjemahan tidak ada yang tidak akurat. Teknik Kesepadanan menyumbang tingkat keakuratan hasil penerjemahan yang baik, baik sebagai teknik yang mandiri maupun bersama dengan teknik Natural Borrowing yaitu 2,79 dan 2,91, hal ini menguatkan pada hasil penelitian Anshori (2010) yang menyatakan hal yang sama. Dhyaningrum (2016) menyatakan bahwa teknik-teknik dominan yang berkontribusi positif terhadap keakuratan terjemahan adalah teknik Kesepadanan lazim, peminjaman murni, peminjaman naturalisasi. Demikian juga Rahmawati (2016) juga menyatakan teknik adaptasi, padanan lazim, generalisasi menghasilkan terjemahan yang akurat. Dinari, Nababan, \& Djatmika, (2017) dalam kajiannya menyatakan bahwa menggunakan teknik kesepadanan lazim memberikan kualitas penerjemahan yang baik

Dengan demikian bisa dinyatakan bahwa hasil terjemahan buku Fundamental of Engineering Thermodynamics karangan Michael J. Moran mempunyai tingkat keakuratan, dan penerjemahan dengan teknik Kesepanan lazim dan Natural borrowing menunjukkan teknik yang baik untuk dipakai. 


\section{(d) analisis komponensial untuk menyusun pola penerjemahan istilah teknik.}

Dari deskripsi data diatas yang berupa bentuk data, sebaran Teknik penerjemahan, dan tingkat keakuratan dapat dirangkum dalam matrik Komponensial seperti pada tabel 3 berikut.

Tabel 3 Matriks komponensial

\begin{tabular}{|c|c|c|c|c|c|c|c|c|}
\hline & $\begin{array}{l}\text { Kesepadanan } \\
\text { Lazim }\end{array}$ & $\begin{array}{l}\text { Natural } \\
\text { Borrowing }\end{array}$ & $\begin{array}{c}\text { Pure } \\
\text { Borrowing }\end{array}$ & $\begin{array}{c}\text { Kes Lazim + } \\
\text { Natural } \\
\text { Borrowing }\end{array}$ & $\begin{array}{c}\text { Kes Lazim + } \\
\text { Pure } \\
\text { Borrowing }\end{array}$ & $\begin{array}{l}\text { Kes Lazim + } \\
\text { Partikularisasi }\end{array}$ & $\begin{array}{l}\text { Kes Lazim + } \\
\text { Amplifikasi }\end{array}$ & $\begin{array}{l}\text { Kes Lazim + } \\
\text { Generalisasi }\end{array}$ \\
\hline Definisi 37 (36\%) & 11 & 3 & 1 & 21 & 1 & 0 & 0 & 0 \\
\hline Skor keakuratan & 2.91 & 2.67 & 2.00 & 2.90 & 3.00 & - & - & - \\
\hline Peralatan $27(27 \%)$ & 5 & 6 & 9 & 6 & 0 & 1 & 0 & 0 \\
\hline Skor keakuratan & 3.00 & 2.67 & 2.67 & 3.00 & 0.00 & 3.00 & - & - \\
\hline Proses $22(22 \%)$ & 10 & 4 & 2 & 5 & 1 & 0 & 0 & 0 \\
\hline Skor keakuratan & 2.7 & 2.8 & 2.5 & 2.8 & 3.0 & - & - & - \\
\hline Kedudukan 5 (5\%) & 4 & 0 & 0 & 0 & 0 & 1 & 0 & 0 \\
\hline Skor keakuratan & 2.50 & - & - & - & - & 3.00 & - & - \\
\hline Ruang 7 (7\%) & 3 & 0 & 0 & 1 & 0 & 1 & 1 & 1 \\
\hline Skor keakuratan & 2.67 & - & - & 3.00 & - & 2.00 & 2.00 & 3.00 \\
\hline Fluida Kerja 4 (4\%) & 1 & 2 & 0 & 0 & 1 & 0 & 0 & 0 \\
\hline Skor keakuratan & 3.00 & 3.00 & - & - & 3.00 & - & - & - \\
\hline Jumlah data & 34 & 15 & 12 & 33 & 3 & 3 & 1 & 1 \\
\hline Skor Keakuratan rata-rata & 2.79 & 2.73 & 2.58 & 2.91 & 3.00 & 2.67 & 2.00 & 3.00 \\
\hline
\end{tabular}

Bahwa pada buku Termodinamika teknik yang disusun oleh Yulianto Sulistyo Nugroho yang merupakan terjemahan buku Fundamental of Engineering Thermodynamics , ini memuat 102 data yang dianalisis, 33 (32\%) berupa kata dan 69 (68\%) berbentuk frasa. Mengandung istilah bermakna Definisi 37 (36\%) dan selainnya $65(64 \%)$ adalah istilah Terapan yang ada pada kelompok makna Peralatan, Proses, Kedudukan, Ruang, dan Fluida kerja. Ungkapan diatas mengisyaratkan bahwa buku ini adalah buku sains terapan karena lebih banyak memuat istilah bermakna terapan daripada bermakna definisi atau konsep.

Kelompok istilah makna Definisi cenderung diterjemahkan dengan dominasi Teknik Kesepadanan lazim baik sendiri maupun dengan teknik lain 33 (89\%), juga dengan teknik Natural borrowing, teknik Pure borrowing. Hasil terjemahan mempunyai skor keakuratan baik yakni $2,9 \div 3,0$.

Kelompok istilah Proses yang bermakna proses termodinamis, diterjemahkan dengan urutan terbanyak adalah teknik Kesepadanan lazim, Natural borrowing, Pure borrowing, Partikulasi dan Generalisasi. Tingkat keakuratannya baik dengan skor $2,7 \div$ 3,0 . 
Istilah teknik Peralatan yang bermakna peralatan yang menunjang terjadinya proses termodinamis, hampir seimbang antara yang berbentuk kata maupun frasa, walau lebih banyak yang berbentuk frasa, diterjemahkan memakai teknik Kesepadanan lazim, Natural borrowing, Pure borrowing, sedikit memakai teknik Partikulasi, mempunyai keakuratan yang dengan skor $2,67 \div 3,0$. Istilah Kedudukan yang bermakna posisi peralatan proses berada, skor $2,5 \div 3,0$. Istilah kelompok Ruang yang bermakna tempat berlangsungnya proses termodinamis skor $2,0 \div 3,0$. Istilah Fluida yang bermakna fluida yang kerja yang berproses termodinamis dengan skor 3,0

Dari bahasan diatas dapatlah dibuat prosedur penerjemahan istilah teknik untuk menghasilkan penerjemahan yang baik yakni :

1. Menggolongkan istilah-istilah teknik tersebut dalam domain-domain Konsep keilmuan, Terapan atau yang lainnya. Dari domain tersebut dijabarkan dalam kelompok-kelompok makna, kemudian semua istilah-istilah dimasukkan dalam kelompok-kelompok tersebut hingga tak bersisa. Hal ini mirip dengan apa yang dilakukan Sigalingging (2014) yang menjabarkan istilah komputer dan teknologi informasi menjadi 6 ranah sosial, beserta 18 kelompok sosiopragmatik, demikian juga Yahya (2012) dalam menganalisis terjemahan kata-kata kultural menggolongkannya dalam ekologi, budaya materi, budaya social, organisasi, gesture.

2. Menerjemahkan istilah-istilah tersebut dengan teknik penerjemahan yang tepat.

3. Menguji keakuratan hasil penerjemahan kepada para rater yang kompeten.

Dengan analisa tema budaya dapat disusun suatu teori terkait penerjemahan istilah teknik, yakni bahwa bahasa Indonesia sudah mampu menyediakan kosa kata yang sepadan dengan bahasa Inggris hingga mampu menyampaikan pesan dari BSu ke dalam BSa dengan tingkat akurasi yang baik.

\section{SIMPULAN}

Analisa hasil terjemahan istilah teknik dalam buku Termodinamika Teknik yang merupakan terjemahan buku Fundamental of Engineering Thermodynamics, dapat disimpulkan bahwa istilah teknik yang terkandung dalam buku tersebut berbentuk kata frasa $69(68 \%)$ dan berbentuk kata 33 (32\%), terbagi dalam domain Konsep keilmuan 
dan domain Terapan, domain Konsep dijabarkan menjadi kelompok Makna (i) Definisi sedangkan domain Terapan dijabarkan menjadi kelompok makna (ii) Peralatan, (iii) Proses, (iv) Kedudukan, (v) Ruang, dan (vi) Fluida Kerja. Istilah teknik tersebut memuat Konsep keilmuan berupa Definisi sebanyak 37 (36\%) dan Terapan 65 (64\%), bahwa istilah terapan tersebut didominasi oleh kelompok makna Peralatan dan Proses.

Penerjemahan istilah teknik pada buku ini didominasi menggunakan Teknik (i) Kesepadanan lazim dari 34 (33\%), dan teknik Borrowing yakni (ii) Natural Borrowing baik maupun (iii) Pure Borrowing sebanyak 27 ( 26\% ). Sedangkan yang lainnya menggunakan (iv) teknik Partikularisasi, 3 (3\%), (v) teknik Amplifikasi, 1 (1\%), dan (vi) teknik Generalisasi, (1\%). Keseluruhan hasil penerjemahan istilah teknik mempuyai tingkat keakuratan yang baik, pada domain Konsep keilmuan 2,67 $\div 3,0$, sedangkan pada domain Terapan $2,5 \div 3,0$. Teknik Kesepadanan lazim merupakan kontributor utama pada keakuratan hasil penerjemahan

Pola penerjemahan istilah teknik untuk menghasilkan penerjemahan yang baik yakni: Menggolongkan istilah-istilah teknik tersebut dalam domain-domain Konsep keilmuan, Terapan atau yang lainnya, kemudian dari domain dijabarkan dalam kelompok-kelompok makna, baru dilakukan penerjemahan dan pengujian keakuratan. Untuk meneguhkan simpulan di atas perlu dilakukan penelitian pada buku-buku teknik pada disiplin ilmu teknik lainnya misalnya bidang manufaktur, teknik informatika, serta buku berhasa asing lain misalnya bahasa Jepang, Jerman. Para peneliti, khususnya dosen dan mahasiswa, dapat menggunakan buku terjemahan yang berjudul Termodinamika Teknik yang disusun oleh Yulianto Sulistyo Nugroho sebagai referensi penelitian penerjemahan istilah teknik karena memiliki tingkat keakuratan yang baik.

\section{DAFTAR PUSTAKA}

Catford, J. C. (1978). A linguistic theory of translation. Oxford: Oxford University Press. Retrieved from http://rahbar.iauq.ac.ir/assets/subdomains/rahbar/files/93/TheoriesOfTranslation/

Chesterman, A. (2017). Reflections on translation theory: Selected papers 1993 - 2014. Amsterdam / Philadelphia: John Benjamin Publishing Company.

Dinari, I., Nababan, M. R., \& Djatmika. (2017). The analysis of translation techniques of irony and sarcasm in novel entitled the return of sherlock holmes and the effects on translation 1. Prasasti: Journal of Linguistic, 2, 69-88. 
Larson, M. L. (1984). Meaning-based translation: A Guide to cross-language equivalence. (A. S. Kaye, Ed.) (Vol. 14). New York: University Press of America. Retrieved from http://doi.org.ololo.sci-hub.cc/10.1016/0024-3841(87)90017-9

Maleong, L. J. (2000). Metodologi penelitian kualitatif. Bandung: PT Remaja Rosda karya.

Molina, L. (2002). Translation techniques revisited: A dynamic and functionalist approach. Meta: Translators' Journal, 47(4), 498. https://doi.org/10.7202/008033ar

Nababan, M. (2012). Pengembangan model penilaian kualitas terjemahan. Kajian Linguistik Dan Sastra, 24(1), 39-57. Retrieved from https://publikasiilmiah.ums.ac.id/bitstream/handle/11617/2220/4. MANGATUR NABABAN.pdf;sequence $=1$

Nurhidayah, V. A. (2015). Analisis teknik dan kualitas terjemahan istilah budaya dalam film "Percy Jackson and the olympians the Lightning thief". Surakarta: Perpustakaan UNS.

Putra, D.A., D., \& Wiratno, T. (2017). Analisis kualitas terjemahan terhadap istilahistilah teknis didalam Game Ragnarok online karya gravity ( Kajian Terjemahan dengan Pendekatan Morfologi). Prasasti: Journal of Linguistics, 2, 36-48.

Sakut, A. (2010). Teknik, metode dan ideologi penerjemahan buku Economic concepts of Ibn Taimiyah kedalam bahasa Indonesia dan dampaknya pada Kualitas Terjemahan. Universitas Sebelas Maret. Retrieved from https://eprints.uns.ac.id/id/eprint/3817

Sigalingging, B. M. (2014). Analisis terjemahan istilah komputer dan teknologi informasi dalam film the social network serta dampaknya pada kualitas terjemahan. UPT Perpustakaan. Universitas Sebelas Maret.

Sutopo, H. B. (2006). Penelitian kualitatif dasar teori dan terapannya dalam penelitian. Surakarta: Universitas Sebelas Maret. 